\title{
Pharmaciana
}

Vol.11, No.2, July 2021, Page. 261-272

ISSN: 2088 4559; e-ISSN: 24770256

DOI: 10.12928/pharmaciana.v11i2.16999

\section{Inhibitory activity of several extract of Piper betle Leaf against Staphylococcus aureus}

\author{
Ahmad Shobrun Jamil ${ }^{* 1}$, Siti Rofida ${ }^{1}$, Dinda Farida ${ }^{1}$, \\ Dwi Retno Nur Syahida ${ }^{2}$, Trimianti Hidahyatun Nazah ${ }^{2}$ \\ ${ }^{I}$ Departmet of Pharmaceutical Biology Faculty of Health Science, University of Muhammadiyah Malang \\ Jl. Bendungan Sutami 188A Malang, East Java, Indonesia \\ ${ }^{2}$ Department of Pharmaceutical Chemistry Faculty of Health Science, University of Muhammadiyah Malang \\ Jl. Bendungan Sutami 188A Malang, East Java, Indonesia
}

Submitted: 03-08-2020

Reviewed: 28-06-2021

Accepted: 27-07-2021

\begin{abstract}
A high number of infections from year to year require infectious diseases to get serious attention. The antimicrobial compound exploration must be continued to anticipate the development of infectious diseases. The purpose of this study was to find out in vitro antimicrobial activity of nhexane, ethyl acetate, and ethanol fractions of Piper betle green leaves against $S$. aureus, and profiles of secondary metabolite compounds contained in these three extracts. The antimicrobial activity test was carried out by disk diffusion test of the fraction of n-hexane, ethyl acetate, and ethanol at a concentration of $6.25,12.5$ and $18.75 \mu \mathrm{g} /$ disk. Detection of secondary metabolite content was done by the Thin Layer Chromatography method with stain-view reagents. The highest antimicrobial activity was found in the ethyl acetate fraction and was significantly different from the activity in the ethanol and n-hexane fractions. However, the antibacterial activity of all fractions was lower compared to the positive control of amoxiclav $30 \mu \mathrm{g} / \mathrm{disk}$. The phytochemical screening results of secondary metabolites of each fraction were shown that the n-hexane fraction contained alkaloids, terpenoids, flavonoids, polyphenols, and anthraquinone; the ethyl acetate fraction contained terpenoids, polyphenols, and anthraquinone; while the ethanol fraction contained alkaloids, terpenoids, polyphenols, and anthraquinone. Based on the test results, it is concluded that all fractions of Piper betle leaf extract had high antimicrobial activity; meanwhile, the ethyl acetate fraction had the highest activities among others. Each fraction was proven to have a different composition of secondary metabolites.
\end{abstract}

Keywords: antimicrobial, ethyl acetate, $n$-hexane, Piper betle, S. aureus

\footnotetext{
*Corresponding author:

Ahmad Shobrun Jamil

Departmet of Pharmaceutical Biology Faculty of Health Science, University of Muhammadiyah Malang Jl. Bendungan Sutami 188A Malang, East Java, Indonesia

Email: shobrun@umm.ac.id
} 


\section{INTRODUCTION}

Disease due to microbial infection is a serious threat today (Neill, 2016). A high number of infections from year to year require infectious diseases to get serious attention. The continued development of infectious diseases and the increase of cases of microorganism resistance to antibiotic drugs require serious action. One of the actions that can be taken is by continuously developing the research on plants that have antimicrobials properties. The plants are widely known as a source of medicinal raw materials, including antimicrobials. Despite advances in drug development through molecular modeling, a combination of chemical drugs and compounds from natural materials is still proven to be very valuable as a source of medicines for humans.

Nature provides abundant ingredients as medicine and these ingredients can be used for infectious diseases. There must be continuous researches to find new sources of antimicrobials to anticipate the emergence of resistance. Piper betle is a plant that is ethnobotanically well-known to be used as an antimicrobial (Avijit and Zerin, 2020; Meinisasti et al., 2020). Some researches on the activity of Piper betle as an antimicrobial has also been conducted. However, in this study, the activities of Piper betle as an antimicrobial will be tested with the continuous separated extraction using three different solvents. The aim is to determine which part of the solvent of the antimicrobial active ingredient can dissolve in. Hence, the active compound can be later fractionated based on its most effective solvent.

Piper betle is a plant species commonly planted by Indonesian people in gardens and parks. This plant has an attractive appearance and its leaves are traditionally used to treat various diseases, especially as an antibacterial (Hartini et al., 2018). The betel leaf extract is known to have better activity as an antimicrobial compared to leaf powder. Alkaloids, phenolics, and saponin are the components with antibacterial activity found in the extract (Guil-Guerrero et al., 2016; Mufrod and Wahyuono, 2016). Empirically, Piper betle leaf is commonly used as a natural antiseptic while its ethanolic extract is proven to have antimicrobial activity against air-borne pathogens (Kusuma et al., 2017). This research, thus, focuses on finding the best solvent that can extract antimicrobial compounds in the betel leaf.

Therefore, a study was conducted to compare the antibacterial activity of the leaf of green betel and red betel, with both extracts' combination. This study calculated the inhibitory activity against Gram-positive and Gram-negative bacteria using a paper agar disk-diffusion method. The combination of those betel leaves and red betel indicated antibacterial activity. The effect of this combination showed an opposing antibacterial activity against S. aureus, Staphylococcus epidermidis, or Escherichia coli. Meanwhile, there were almost no significant differences in the antibacterial activity against those three bacteria between the betel leaves and red betel (Hartini et al., 2018).

Several studies have also been conducted to observe the antimicrobial activity of Piper betle. A study was performed to compare the antimicrobial activity of garlic extract (Allium sativum), garlic (Allium tuberosum), and betel leaf (Piper betle) on six pathogenic bacteria in the aquaculture of Oreochromis niloticus fish. The study concluded that the betel leaf-ethanolic extract showed the strongest antibacterial activity (Ataguba et al., 2018).

Another analysis of the betel leaf-methanolic extract showed that gas chromatography-gas mass spectrometry had identified the 4-allylpyrocatechol, eugenol, $\alpha$-pinene, and $\beta$-pinene in methanol extract. According to the study, the compounds extracted from $P$. betle leaves are proven to be used as a substitution for chemical fungicide in viticulture (Aoki et al., 2019).

Meanwhile, S. aureus is a bacterium that causes infection. This bacterium is also known to have resistance to several antibiotics. Some strains of $S$. aureus even have resistance to antibiotics and are known as MRSA. In this study, S. aureus was used as a test bacterium considering that it is the most common bacterium causing infections with high spreadability.

The purpose of this study was to observe in vitro; antimicrobial activity of the n-hexane, ethyl acetate, and ethanol extract of Piper betle leaves against S. aureus. Meanwhile, the profiles of secondary metabolite compounds in the fractions of n-hexane, ethyl acetate, and ethanol from Piper 
betle leaves were also reported through a phytochemical screening with Thin Layer Chromatography (TLC).

\section{MATERIALS AND METHOD}

\section{Materials}

Piper betle leaf powder was obtained from UPT. Materia Medika Batu and has been identified by the determination letter number 074/334.A/102.7/2018. Staphylococcus aureus. aureus obtained from Biomedical Laboratory of the Faculty of Medicine, University of Muhammadiyah Malang. Nutrient Agar (Sigma Aldrich / Merck) was used as the test medium. The n-hexane, ethanol, and ethyl acetate solvents pro analysis and Heidolph rotary evaporator were provided by the Integrated Chemistry Laboratory of Pharmacy Study Program, University of Muhammadiyah Malang.

\section{Methods}

\section{Extraction}

The extraction method is a modification of the previous method from (Felhi et al., 2017; Jamil et al., 2012; Janmanchi et al., 2017). The extract was obtained by maceration of Piper betle leaf powder $(5 \mathrm{~g})$ in three types of solvents $(25 \mathrm{~mL}$ x 2 , each solvent) sequentially from $\mathrm{n}$-hexane, ethyl acetate, and ethanol for 48 hours at room temperature with continuous agitation as depicted in Figure 1. The suspension of Piper betle leaf powder in n-hexane solvent was filtered using a filter paper. The filtrate of n-hexane extract (ENH) was collected in a container and the wet powder was dried. The dry powder from n-hexane maceration was then macerated with ethyl acetate solvent, filtered, and ethyl acetate extract (EEA) was collected as in the first procedure. The dry powder from the ethyl acetate was then macerated with ethanol, filtered, and then was collected as in the first and second procedures. The three types of extract were then concentrated separately using a rotary evaporator.

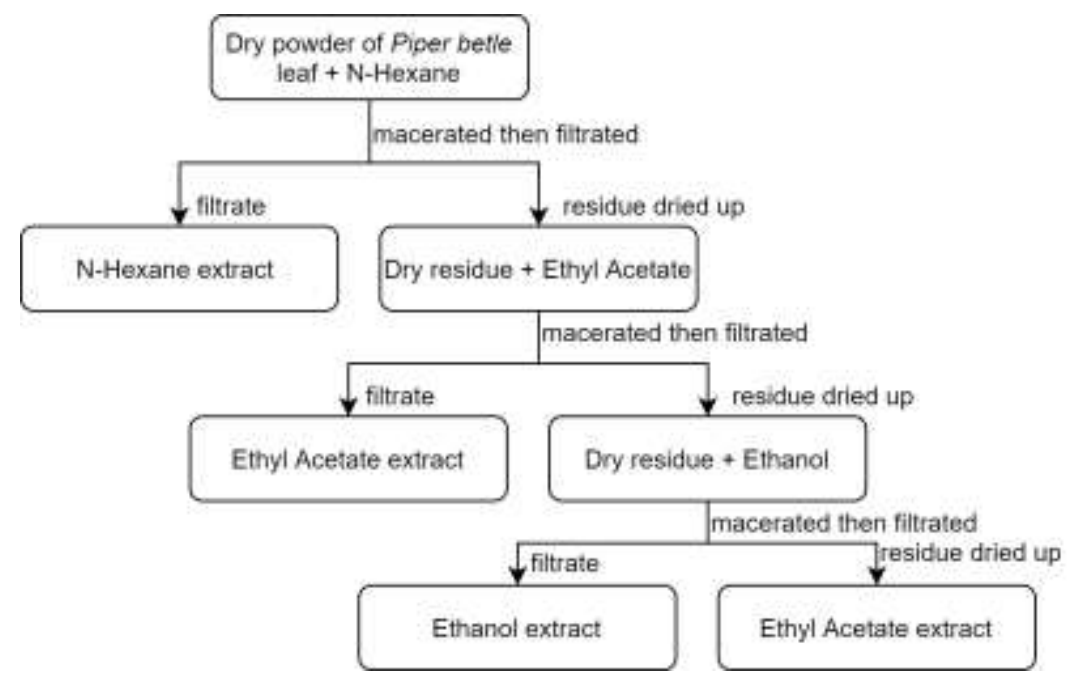

Figure 1. Extraction schemes of Piper betle leaf with three different solvents

\section{Phytochemical screening}

Five microliters of each sample fraction were spilled on a silica gel TLC 60 F254 chromatography plate (Merck, TLC grade) as a stationary phase. Each plate was placed in a glass chromatography chamber containing eluents (Ethyl acetate: Chloroform (6:4); Ethyl acetate: Chloroform (3:7); Ethyl acetate: Methanol (8:2); Ethyl acetate: Chloroform (5:5); Ethyl acetate: Chloroform (4:6) n-hexane: Ethyl acetate (7:3); n-hexane: Ethyl acetate (8:2) for optimization. The plate in the chamber containing the eluent separated the compounds optimally on the chromatogram that was taken and sprayed with several reagents such as Dragendorf, Anisaldehyde-sulfuric acid, 
sulfuric acid concentrated, $\mathrm{FeCl}_{3}$, and $\mathrm{KOH}$ solution. The Rf value of spots on the chromatograms was visually viewed and calculated, where the Rf is the distance traveled by analytes / the distance traveled by the solvent (Harborne, 1984; Stahl, 1969).

\section{Antibacterial activity test}

Antibacterial activity test was performed by disk diffusion method (Balouiri et al., 2016; María et al., 2018; Mostafa et al., 2018). Each fraction (n-hexane, ethyl acetate, and ethanol) of green betel leaf (Piper betle L.) was tested in vitro with a negative control group (aquadest and DMSO 1\%) and a positive control group (Amoxiclav $30 \mu \mathrm{g}$ ). The test concentrations used were 6.25, 12.5 and 18.75 $\mu \mathrm{g} / \mathrm{disk}$. The antibacterial activity of each fraction of green bêtel leaf (Piper betle L.) against S. aureus was obtained by measuring the diameter of the inhibition zone around the disk paper.

\section{Data analysis for antibacterial activity test}

The antibacterial activity data is statistically analyzed and calculated using SPSS version 23 by comparing the inhibition zone diameter of the clear zone of each concentration in each test group of betel leaf (Piper betle L.) against S. aureus.

\section{RESULT AND DISCUSSION}

Phytochemical screening

Piper betle is known to have bioactive compounds that can be used to treat various diseases. It has been reported that Piper betle has anti-inflammatory, antioxidant, antibacterial, anti-fungal, antimalarial, and anticancer activities (Mgbeahuruike et al., 2017). This study, nonetheless, focused on observing the antibacterial activity of Piper betle fractionated by the method in Figure 1. The presence of bioactive compounds such as alkaloids, terpenoids, polyphenol, flavonoids, anthraquinones of all fractions (Table 1) was confirmed to be the same as the previous study (Syahidah et al., 2017) with identical stain colors on the chromatogram.

In this study, the Piper betle n-hexane extract (ENH) contained alkaloids, terpenoids, polyphenol, flavonoids, anthraquinone (Table 1), with the TLC detection method with stain appearances (Table 2). This would be different from the previous study (Junairiah et al., 2018) that used liquid-liquid fractionation, where the n-hexane fraction only contained terpenoids from five types of metabolites detected (alkaloids, terpenoids, tannin, flavonoids, saponins).

The chromatogram of EET, EEA, and ENH extracts of Piper betle leaves was done according to the Harborne method (Harborne, 1984; María et al., 2018), where it identifies several compounds suspected of having antibacterial activity including alkaloids, terpenoids, flavonoids, polyphenols, and anthraquinone.

According to the results of phytochemical screening (Table 1), the three extracts (EET, EEA, and ENH) contained polyphenols. Syahidah et al. (2017) stated that polyphenols show antimicrobial activity. Phenolic derivatives such as hydroxichavicol and eugenol are also proven to have inhibitory activity for microbial growth. The activity is in the form of growth inhibitory activity which correlates with the amount of compound content in the extract, where the higher the extract concentration is, the higher the inhibitory activity (Syahidah et al., 2017). 
Table 1. Phytochemical screening results, secondary metabolite content of alkaloids, terpenoids, flavonoids, polyphenols, and anthraquinones in each of the Piper betle leaf extract

\begin{tabular}{|c|c|c|c|c|c|c|c|c|c|c|}
\hline Compound & $\begin{array}{l}\text { Spot } \\
\text { visualization by }\end{array}$ & Rf & $\begin{array}{l}\text { hanolic Ex } \\
\text { Colour of } \\
\text { the } \\
\text { spot/band }\end{array}$ & $\begin{array}{l}\text { act } \\
\text { Result }\end{array}$ & $\begin{array}{l}\text { Eth } \\
\text { Rf }\end{array}$ & $\begin{array}{l}\text { Acetate Ex } \\
\text { Colour of } \\
\text { the } \\
\text { spot/band }\end{array}$ & $\begin{array}{l}\text { ract } \\
\text { Result }\end{array}$ & Rf & $\begin{array}{l}\text { Hexane Ext } \\
\text { Colour of } \\
\text { the } \\
\text { spot/band }\end{array}$ & Result \\
\hline Alkaloid & Dragendorff & 0.29 & Orange & + & - & - & - & 0.14 & Orange & + \\
\hline Flavonoid & $\begin{array}{l}\text { Conc.Sulfuric } \\
\text { Acid }\end{array}$ & - & - & - & - & - & - & 0.08 & $\begin{array}{l}\text { Intensive } \\
\text { yellow }\end{array}$ & + \\
\hline Terpenoid & $\begin{array}{l}\text { Anisaldehyde- } \\
\text { Sulfuric Acid }\end{array}$ & 0.28 & $\begin{array}{l}\text { Purplish } \\
\text { red }\end{array}$ & + & $\begin{array}{c}\text { Rf } 1= \\
0.4\end{array}$ & Purple & + & 0.56 & Purple & + \\
\hline & & 0.45 & $\begin{array}{l}\text { Purplish } \\
\text { red }\end{array}$ & + & $\begin{array}{c}\operatorname{Rf} 2= \\
0.6 \\
\operatorname{Rf} 3= \\
0.7\end{array}$ & $\begin{array}{l}\text { Purplish } \\
\text { red } \\
\text { purplish } \\
\text { red }\end{array}$ & + & - & - & \\
\hline Polyphenol & $\mathrm{FeCl}_{3}$ & 0.4 & Black & + & 0.4 & Black & + & 0.25 & Black & + \\
\hline $\begin{array}{l}\text { Anthraquin } \\
\text { one }\end{array}$ & $\begin{array}{l}\mathrm{KOH} 10 \% \text { in } \\
\text { methanol }\end{array}$ & 0.27 & Yellow & + & 0.41 & brownish & + & 0.41 & Red Purple & + \\
\hline
\end{tabular}

Based on the phytochemical screening results, the ENH, EEA, and FET also contained terpenoids. Terpenoids are known to have the activity of destroying membrane integrity thereby increasing the permeability of bacterial cell membranes. Terpenoid derivatives in the fraction may also interfere with various cellular activities, which include production of energy, transport of membrane, and other metabolic regulation functions. Terpenoids also interfere with cell membranes that help numerous vital processes including energy conversion processes, nutrient processing, synthesis of structural macromolecules, and growth-regulating secretions (Oussalah et al., 2006; Swamy et al., 2016).

The alkaloid content in Piper betle (Mgbeahuruike et al., 2017) has the activity to reduce bacteria's ability to attach to the host, inhibit biofilm formation and inhibit bacterial cell cytokinesis. Alkaloids and their derivatives are also known to have a synergistic effect with antibiotics streptomycin, vancomycin, clindamycin, and erythromycin that have been shown to increase the inhibitory activity of multi-resistant resistant bacteria (MDR) (Barbieri et al., 2017). Research conducted by Dusane et al. (2014) showed that the alkaloid in Piper nigrum which is one genus with Piper betle has an activity to reduce bacterial colonization activity and motility and inhibit the formation of biofilms (Dusane et al., 2014).

The hydrophobic nature of some phenolic compounds may be the main factor that is responsible for antimicrobial activity (Pyla et al., 2010). The mechanism of polyphenol microbial toxicity can be associated with hydrolytic enzymes (proteases) inhibition or other interactions that inhibit microbial adhesion, cell membrane transport proteins, and non-specific interactions with carbohydrates in cell walls (Baba and Malik, 2015; Marín et al., 2015).

Anthraquinone which is isolated from several plants is known to have high activity as an antimicrobial (Duval et al., 2016). Quinones have several protein targets including bacterial cell adhesin proteins, polypeptides, and cell walls. Anthraquinone also activates several important enzymes in bacterial metabolism (Bilal et al., 2017; Pandey et al., 2014) especially membrane-bound enzymes (Upadhyay et al., 2014). 
Table 2. Chromatogram spot and color profile from three different extracts of EET (Ethanol Extract), EEA (Ethyl Acetate Extract), ENH (n-hexane Extract) after being sprayed by spot visualization reagent

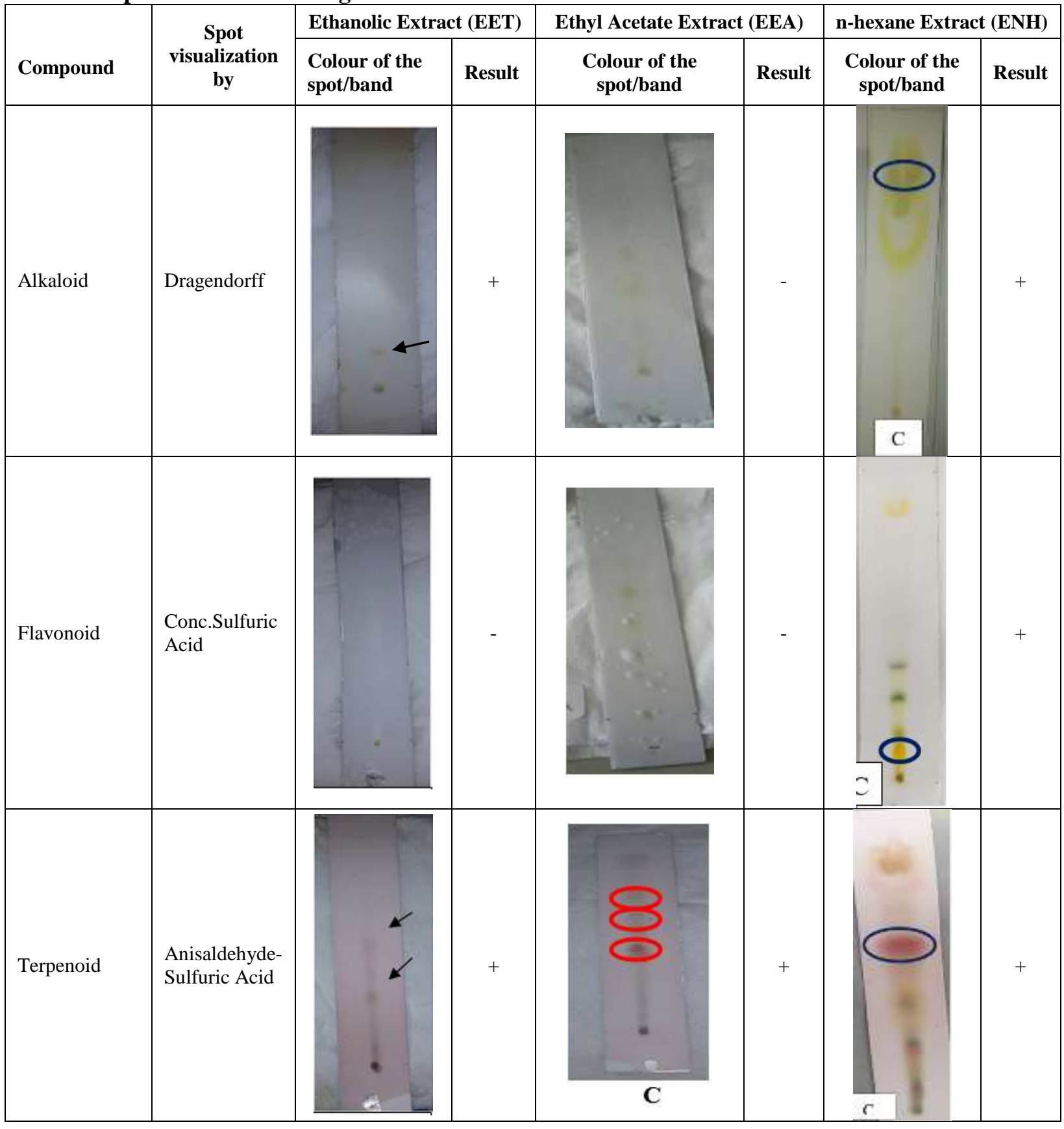




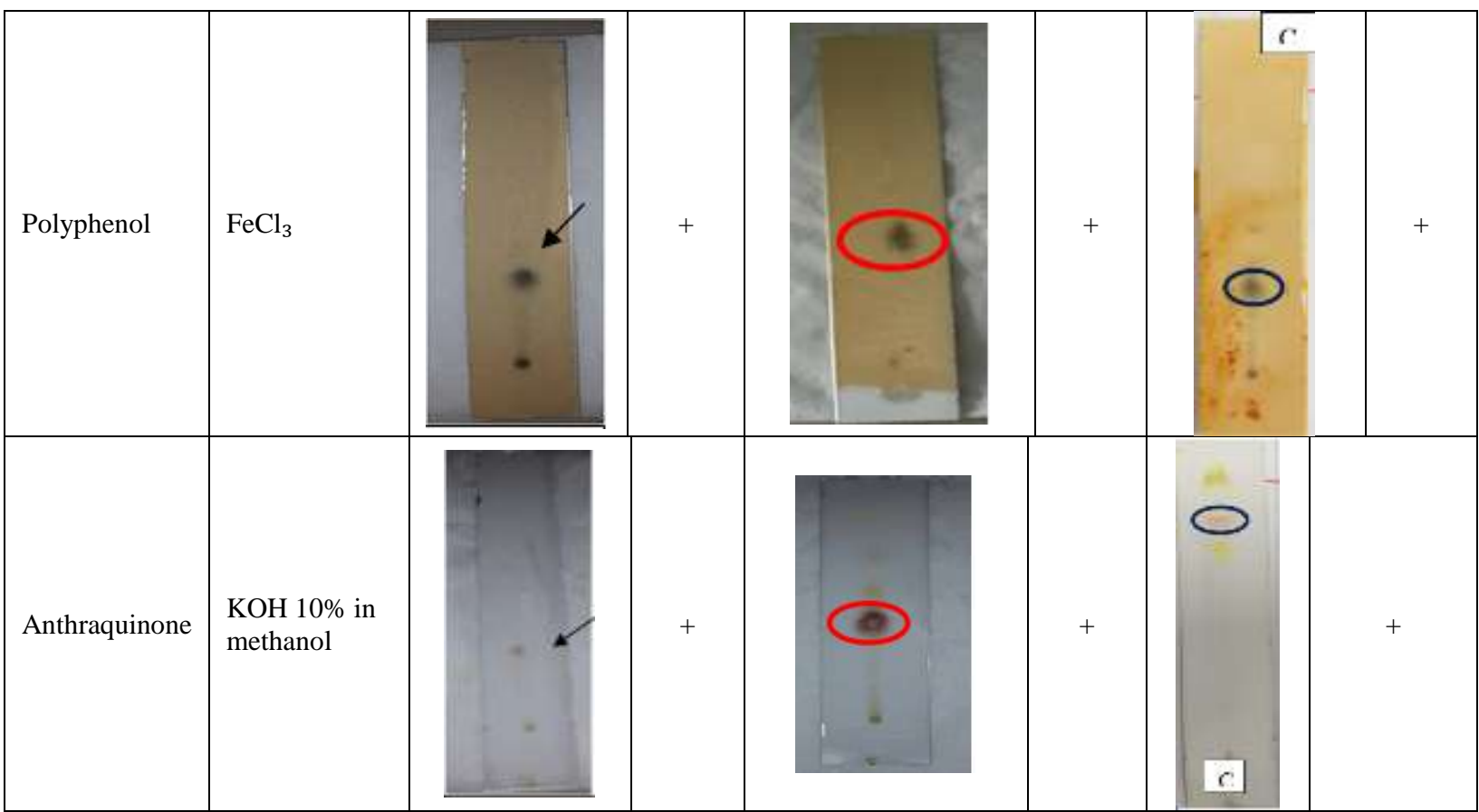

\section{Antibacterial activity}

With various previous research references, this study's purpose is to demonstrate the antibacterial activity of the n-hexane extract (ENH), ethyl acetate extract (EEA), and ethanol extract (FET) obtained by the stratified extraction method to $S$. aureus. S. aureus is a common pathogen that infects humans. This bacterium can cause several infections such as endocarditis, bacteremia, skin infections, soft tissue, lungs, and other infections (Tong et al., 2015). S. aureus itself is a type of bacteria that has high speed and uniqueness in eliciting resistance activity. Moreover, the issue of Methicillin-resistant $S$. aureus (MRSA) has become a troublesome case for hospitals in the world (Kaur and Chate, 2015). Therefore, it is necessary to carry out continuous development of antibiotic drugs including exploration of natural ingredients as the main source of antibiotics.

This study was conducted to determine the antibacterial potential of the Piper betle leaf extract with three types of solvent namely n-hexane, ethyl acetate, and ethanol solvents. This extraction method is used to observe which solvent is the most effective to see which compound has the strongest antimicrobial activity. The extracted compound with the strongest ability is used to isolate the active compounds from plants so they can also be developed to isolate the antibacterial active ingredient. This research is the first step and is limited only to the observation of the activity and class of secondary metabolite compounds contained in Piper betle leaf powder.

The results of the antimicrobial test using the diffusion method of ethanol extract, ethyl acetate extract, and n-hexane extract (Table 3) showed that all EET, EEA, and ENH extracts had inhibitory activity against $S$. aureus. It shows that in the ethanol extract (Kavitha and Jeevaratnam, 2016), ethyl acetate, and n-hexane contained antibacterial compounds from the Piper betle leaf (Mgbeahuruike et al., 2017). Also, the antimicrobial activity of Piper betle leaf extract was regarded more potent in Gram-positive bacteria (Valle et al., 2016). 
Table 3. The results of the measurement of the zone of inhibition of the growth of $S$. aureus bacteria with the test solution of EET (Ethanol Extract), EEA (Ethyl Acetate Extract), ENH (n-hexane Extract) with positive control amoxiclav

\begin{tabular}{lccc}
\hline \begin{tabular}{c} 
Treatment \\
\multicolumn{1}{c}{$\mu \mathrm{g} / \mathrm{disk}$}
\end{tabular} & $\begin{array}{c}\text { Ethanol Extract } \\
(\mathrm{EET})\end{array}$ & $\begin{array}{c}\text { Ethyl Acetate Extract } \\
(\text { EEA) }\end{array}$ & $\begin{array}{c}\text { N-Hexane Extract } \\
(\text { ENH) }\end{array}$ \\
\hline 6.25 & $10.03 \pm 1.08^{\mathrm{a}}$ & $15.83 \pm 2.36^{\mathrm{b}}$ & $8.88 \pm 0.99^{\mathrm{a}}$ \\
12.5 & $10.62 \pm 1.70^{\mathrm{a}}$ & $16.10 \pm 0.66^{\mathrm{b}}$ & $8.95 \pm 0.67^{\mathrm{a}}$ \\
18.75 & $11.30 \pm 1.41^{\mathrm{a}}$ & $16.65 \pm 1.65^{\mathrm{b}}$ & $9.40 \pm 0.36^{\mathrm{a}}$ \\
Amoxyclav 30 $\mu \mathrm{g} /$ disk & $25.58 \pm 1.75^{\mathrm{c}}$ & $25.40 \pm 0.61^{\mathrm{c}}$ & $24.65 \pm 3.20^{\mathrm{c}}$ \\
Blank & 0.00 & 0.00 & 0.00 \\
\hline
\end{tabular}

(different letters of "a,b,c" that are labeled in the diameter of inhibition zone indicate significant differences between treatments)
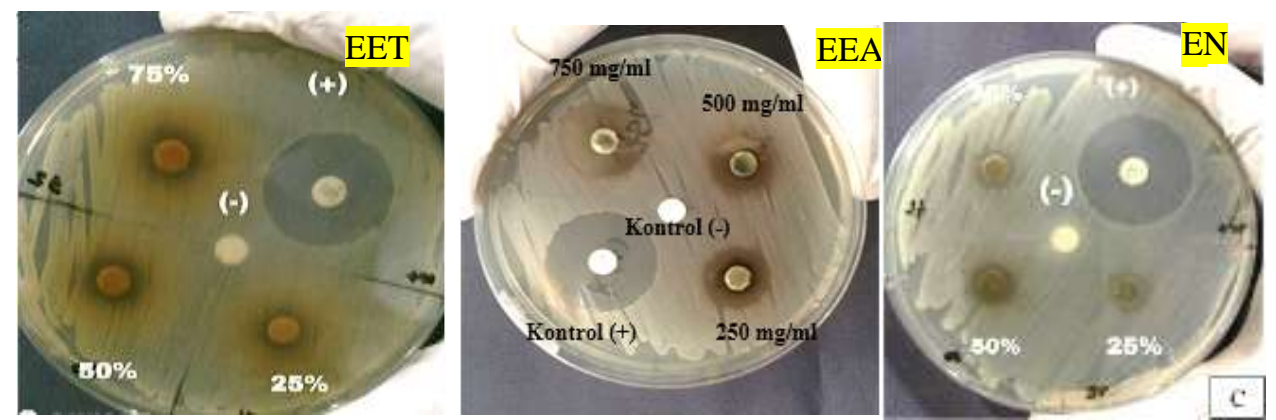

Figure 2. Disk diffusion test results: EET (Ethanol Extract), EEA (Ethyl Acetate Extract), ENH (n-hexane Extract) with positive control of amoxiclav $30 \mu \mathrm{g} / \mathrm{disk}(75 \%=18,75 \mu \mathrm{g} / \mathrm{disk} ; 50 \%=12,5 \mu \mathrm{g} / \mathrm{disk}$; $25 \%=6,26 \mu \mathrm{g} / \mathrm{disk})$

The antibacterial activity in each extract was not significantly different at concentrations of $6.25 ; 12.5$ and $18.75 \mu \mathrm{g} / \mathrm{disk}$ (Table 3 ). The highest bacterial inhibition was found in EEA which was significantly different from EET and ENH (Table 3). According to Waghmode et al. study, the extract of Piper betle leaves in ethyl acetate had the highest antimicrobial activity compared to ethanol and nhexane (Waghmode et al., 2017), while other studies used several extracts, proving that the ethyl acetate extract obtained from plants had higher antimicrobial activity than extracts of butanol, nhexane and other solvents (Su et al., 2015; Wang et al., 2016). On the other hand, also in other studies, the ethyl acetate extract from plant extracts showed the same antimicrobial activity as the n-hexane extract (Ajileye et al., 2015). This shows that extraction method and plant species/species determine their antimicrobial activity. Disk diffusion test results (Figure 2) also showed that all extracts with test concentrations had lower antimicrobial activity compared to positive controls in the form of antibiotic amoxiclav as the positive control.

The different extraction methods appear to cause different antimicrobial efficacy. Based on research (Singh et al., 2019), ethanol extract of Piper betle extracted with methanol and aquadest solvents showed the best antimicrobial activity in ethanol extract but this will be different from this study where ethyl acetate extract was known to have the best activity compared to ethanol and nhexane extracts. It seems that the extraction using ethyl acetate solvent in some plants resulted in higher antibacterial activity than the other tested extracts (Hidayati et al., 2019; Ibrahim et al., 2018).

Another research stated that the extracts of ethanol, petroleum ether, and chloroform, which were tested against Gram-positive and Gram-negative bacteria with disk diffusion method, showed broadspectrum of antibacterial activity by inhibiting the growth of gram-positive and gram-negative bacteria 
including S. aureus. Petroleum ether extract from Piper betle was the least effective against most of the organisms tested. Moderate antibacterial activity was present in chloroform extracts while ethanol extract showed optimal activity for almost all selected strains (Bangash et al., 2012).

\section{CONCLUSION}

The n-hexane, ethyl acetate, and ethanol extracts of Piper betle leaf showed inhibitory activity on the growth of Staphylococcus aureus. The highest activity was found in the ethyl acetate extract. Based on the detection of alkaloids, flavonoids, terpenoids, polyphenols, and anthraquinone, the bioactive compounds in Piper betle with TLC method resulted in ENH containing 5 of 5 detected bioactive compounds. EEA contained 3 out of 5 bioactive compounds tested and EET contained 4 out of 5 compounds tested.

\section{ACKNOWLEDGEMENT}

This research was funded by a block-grant fund from the Health Faculty of Muhammadiyah University of Malang number E.6/872/FIKES-UMM/VIII/2019.

\section{REFERENCES}

Ajileye, O. O., Obuotor, E. M., Akinkunmi, E. O., \& Aderogba, M. A. (2015). Isolation and characterization of antioxidant and antimicrobial compounds from Anacardium occidentale L. (Anacardiaceae) leaf extract. Journal of King Saud University - Science, 27(3), 244-252. https://doi.org/10.1016/j.jksus.2014.12.004

Aoki, Y., Van Trung, N., \& Suzuki, S. (2019). Impact of piper betle leaf extract on grape downy mildew: Effects of combining 4-allylpyrocatechol with eugenol, $\alpha$-pinene or $\beta$-pinene. Plant Protection Science, 55(1), 23-30. https://doi.org/10.17221/53/2018-PPS

Ataguba, G. A., Dong, H. T., Rattanarojpong, T., Senapin, S., \& Salin, K. R. (2018). Piper betle Leaf Extract Inhibits Multiple Aquatic Bacterial Pathogens and In Vivo Streptococcus agalactiae Infection in Nile Tilapia. Turkish Journal of Fisheries and Aquatic Sciences, 61(3), 1-37. https://doi.org/10.4194/1303-2712-v18

Avijit, B., \& Zerin, T. (2020). Comparative Phytochemical and Antibacterial properties of Piper betle Leave Extracts from Barguna and Moheshkhali, Bangladesh. 14(2), 125-132

Baba, S. A., \& Malik, S. A. (2015). Determination of total phenolic and flavonoid content, antimicrobial and antioxidant activity of a root extract of Arisaema jacquemontii Blume . Journal of Taibah University for Science, 9(4), 449-454. https://doi.org/10.1016/j.jtusci.2014.11.001

Balouiri, M., Sadiki, M., \& Ibnsouda, S. K. (2016). Methods for in vitro evaluating antimicrobial activity: A review. Journal of Pharmaceutical Analysis, 6(2), 71-79. https://doi.org/10.1016/i.jpha.2015.11.005

Bangash, F. A., Hashmi, A., Mahboob, A., Zahid, M., Hamid, B., Muhammad, S., Shah, Z., \& Afzaal, H. (2012). In-Vitro Antibacterial activity of Piper Betel Leaf extracts. Journal of Applied Pharmacy, 4(04), 196-203. https://doi.org/10.21065/19204159.4.196

Barbieri, R., Coppo, E., Marchese, A., Daglia, M., Sobarzo-Sánchez, E., Nabavi, S. F., \& Nabavi, S. M. (2017). Phytochemicals for human disease: An update on plant-derived compounds antibacterial activity. Microbiological Research, 196, 44-68. https://doi.org/10.1016/j.micres.2016.12.003

Bilal, M., Rasheed, T., Iqbal, H. M. N., Hu, H., Wang, W., \& Zhang, X. (2017). Macromolecular agents with antimicrobial potentialities: A drive to combat antimicrobial resistance. International Journal of Biological Macromolecules, 103, 554-574. https://doi.org/10.1016/j.ijbiomac.2017.05.071

Dusane, D. H., Hosseinidoust, Z., Asadishad, B., \& Tufenkji, N. (2014). Alkaloids modulate motility, biofilm formation and antibiotic susceptibility of uropathogenic Escherichia coli. PLoS ONE, 9(11), 1-9. https://doi.org/10.1371/journal.pone.0112093

Duval, J., Pecher, V., Poujol, M., \& Lesellier, E. (2016). Research advances for the extraction, analysis Inhibitory activity of several ... (Jamil et al.,) 
and uses of anthraquinones: A review. Industrial Crops and Products, 94, 812-833. https://doi.org/10.1016/j.indcrop.2016.09.056

Felhi, S., Daoud, A., Hajlaoui, H., Mnafgui, K., Gharsallah, N., \& Kadri, A. (2017). Solvent extraction effects on phytochemical constituents profiles, antioxidant and antimicrobial activities and functional group analysis of Ecballium elaterium seeds and peels fruits. Food Science and Technology, 37(3), 483-492. https://doi.org/10.1590/1678-457x.23516

Guil-Guerrero, J. L., Ramos, L., Moreno, C., Zúñiga-Paredes, J. C., Carlosama-Yepez, M., \& Ruales, P. (2016). Antimicrobial activity of plant-food by-products: A review focusing on the tropics. Livestock Science, 189, 32-49. https://doi.org/10.1016/j.livsci.2016.04.021

Harborne. (1984). Phytochemical Methods: A Guide to Modern Techniques of Plant Analysis. second ed., Chapman and Hall, New York, USA. In Chapmer and Hall

Hartini, Y. S., Seta Diaseptana, Y. M., Nugraheni Putri, R., \& Susanti, L. E. (2018). Antagonistic Antibacterial Effect of Betel and Red Betel Combination against Gram-positive and Gramnegative Bacteria. International Journal of Current Microbiology and Applied Sciences, 7(05), 267-272. https://doi.org/10.20546/ijcmas.2018.705.035

Hidayati, D. N., Hidayati, N., Evinda, E., Fitriana, N. R., \& Kusumadewi, A. P. (2019). Antibacterial Activity of Leucaena leucocephala Leaf Extract Ointment against Staphylococcus aureus and Staphylococcus $\quad$ epidermidis. $\quad$ Pharmaciana, $175-182$. https://doi.org/10.12928/pharmaciana.v9i1.12328

Houghton, P. J., \& Raman, A. (1998). Laboratory handbook for the extractation of natural extracts. In Laboratory Handbook for the Extractation of Natural Extracts (1th ed.). International Thompson Publishing. https://doi.org/10.1007/978-1-4615-5809-5

Ibrahim, A. M., Lawal, B., Abubakar, A. N., Tsado, N. A., Kontagora, G. N., Gboke, J. A., \& Berinyuy, E. B. (2018). Antimicrobial and free radical scavenging potentials of n-hexane and ethyl acetate extracts of Phyllanthus Fraternus. Nigerian Journal of Basic and Applied Sciences, 25(2), 6. https://doi.org/10.4314/njbas.v25i2.2

Jamil, M., ul Haq, I., Mirza, B., \& Qayyum, M. (2012). Isolation of antibacterial compounds from Quercus dilatata L. through bioassay guided extractation. Annals of Clinical Microbiology and Antimicrobials, 11(11), 1-11. https://doi.org/10.1186/1476-0711-11-11

Janmanchi, H., Raju, A., Degani, M. S., Ray, M. K., \& Rajan, M. G. R. (2017). Antituberculosis, antibacterial and antioxidant activities of Aegiceras corniculatum, a mangrove plant and effect of various extraction processes on its phytoconstituents and bioactivity. South African Journal of Botany, 113, 421-427. https://doi.org/10.1016/j.sajb.2017.09.019

Junairiah, Ni'matuzahroh, Istighfari, N., Zuraidassanaaz, \& Sulistyorini, L. (2018). Isolation and indetification of secondary metabolites of black betel (Piper betle L var nigra). Jurnal Kimia Riset, 3(2), 131-138. https://doi.org/10.1017/CBO9781107415324.004

Kaur, D. C., \& Chate, S. S. (2015). Study of antibiotic resistance pattern in methicillin resistant staphylococcus aureus with special reference to newer antibiotic. Journal of Global Infectious Diseases, 7(2), 78-84. https://doi.org/10.4103/0974-777X.157245

Kavitha, S., \& Jeevaratnam, K. (2016). Molecular characterization of lactobacilli isolated from Piper betle L. var. Pachaikodi and Comparative Analysis of the Antimicrobial Effects of Isolate Lactobacillus plantarum KJB23 and Betel Leaves Extract. Food Biotechnology, 30(2), 123-136. https://doi.org/10.1080/08905436.2016.1166440

Kusuma, S., Mita, S., \& Mutiara, A. (2017). Antimicrobial lotion containing red Piper betle leaf (Piper crocatum Ruiz and Pav) ethanolic extract for topical application. National Journal of Physiology, Pharmacy and Pharmacology, 8(1), 1. https://doi.org/10.5455/njppp.2018.8.1042115112017

María, R., Shirley, M., Xavier, C., Jaime, S., David, V., Rosa, S., \& Jodie, D. (2018). Preliminary phytochemical screening, total phenolic content and antibacterial activity of thirteen native species from Guayas province Ecuador. Journal of King Saud University - Science, 30(4), 500505. https://doi.org/10.1016/j.jksus.2017.03.009 
Marín, L., Miguélez, E. M., Villar, C. J., \& Lombó, F. (2015). Bioavailability of dietary polyphenols and gut microbiota metabolism: Antimicrobial properties. BioMed Research International, 2015. https://doi.org/10.1155/2015/905215

Meinisasti, R., Muslim, Z., \& Sunita, R. (2020). The effectiveness test of Piper Betle Leaf ethanol extract cream ( Piper Betle Linn ) toward propionibacterium acnes bacterial growth. Bioscientia Medicina, 4(2), 10-17

Mgbeahuruike, E. E., Yrjönen, T., Vuorela, H., \& Holm, Y. (2017). Bioactive compounds from medicinal plants: Focus on Piper species. South African Journal of Botany, 112, 54-69. https://doi.org/10.1016/j.sajb.2017.05.007

Mostafa, A. A., Al-askar, A. A., Almaary, K. S., Dawoud, T. M., Sholkamy, E. N., \& Bakri, M. M. (2018). Saudi Journal of Biological Sciences Antimicrobial activity of some plant extracts against bacterial strains causing food poisoning diseases. Saudi Journal of Biological Sciences, 25(2), 361-366. https://doi.org/10.1016/j.sjbs.2017.02.004

Mufrod, S., \& Wahyuono, and S. (2016). Piper betle Leaves Extract Patch: Evaluation Of Antibacterial Activity, Release Profile Of Eugenol, And Local Tolerance. Traditional Medicine Journal, 21(2), 104-110. Https://Doi.Org/10.22146/Tradmedj.12825

Neill, J. I. M. O. (2016). Tackling drug-resistant infections globally: final report and recommendations the review on antimicrobial resistance (Issue May)

Oussalah, M., Caillet, S., \& Lacroix, M. (2006). Mechanism of action of Spanish oregano, Chinese cinnamon, and savory essential oils against cell membranes and walls of Escherichia coli O157:H7 and Listeria monocytogenes. Journal of Food Protection, 69(5), 1046-1055. https://doi.org/10.4315/0362-028X-69.5.1046

Pandey, S., Satpathy, G., \& Gupta, R. K. (2014). Evaluation of nutritional, phytochemical , antioxidant and antibacterial activity of exotic fruit " Limonia acidissima . "3(2), 81-88

Pyla, R., Kim, T., Silva, J. L., \& Jung, Y. (2010). International Journal of Food Microbiology Enhanced antimicrobial activity of starch-based fi $1 \mathrm{~m}$ impregnated with thermally processed tannic acid , a strong antioxidant. International Journal of Food Microbiology, 137(2-3), 154160. https://doi.org/10.1016/j.ijfoodmicro.2009.12.011

Singh, T. P., Chauhan, G., Agrawal, R. K., \& Mendiratta, S. K. (2019). In vitro study on antimicrobial, antioxidant, FT-IR and GC-MS/MS analysis of Piper betle L. leaves extracts. Journal of Food Measurement and Characterization, 13(1), 466-475. https://doi.org/10.1007/s11694-018-9960-8

Stahl, E. (1969). Thin-Layer Chromatography A Laboratory Handbook. In Journal of Chemical Information and Modeling (Issue 2). Springer Berlin Heidelberg. https://doi.org/10.1007/978-3$\underline{642-88488-7}$

Su, P. W., Yang, C. H., Yang, J. F., Su, P. Y., \& Chuang, L. Y. (2015). Antibacterial activities and antibacterial mechanism of polygonum cuspidatum extracts against nosocomial drug-resistant pathogens. Molecules, 20(6), 11119-11130. https://doi.org/10.3390/molecules200611119

Swamy, M. K., Akhtar, M. S., \& Sinniah, U. R. (2016). Antimicrobial properties of plant essential oils against human pathogens and their mode of action: An updated review. Evidence-Based Complementary and Alternative Medicine, 2016, 1-21. https://doi.org/10.1155/2016/3012462

Syahidah, A., Saad, C. R., Hassan, M. D., Rukayadi, Y., Norazian, M. H., \& Kamarudin, M. S. (2017). Phytochemical analysis, identification and quantification of antibacterial active compounds in betel leaves, piper betle methanolic extract. Pakistan Journal of Biological Sciences, 20(2), 7081. https://doi.org/10.3923/pjbs.2017.70.81

Tong, S. Y. C., Davis, J. S., Eichenberger, E., Holland, T. L., \& Fowler, V. G. (2015). Staphylococcus aureus infections: Epidemiology, pathophysiology, clinical manifestations, and management. Clinical Microbiology Reviews, 28(3), 603-661. https://doi.org/10.1128/CMR.00134-14

Upadhyay, A., Upadhyaya, I., Kollanoor-Johny, A., \& Venkitanarayanan, K. (2014). Combating Pathogenic Microorganisms Using Plant-Derived Antimicrobials: A Minireview of the Mechanistic Basis. BioMed Research International, 2014. https://doi.org/10.1155/2014/761741

Valle, D. L., Cabrera, E. C., Puzon, J. J. M., \& Rivera, W. L. (2016). Antimicrobial activities of 
methanol, ethanol and supercritical CO2 extracts of philippine Piper betle L. on clinical isolates of Gram positive and Gram negative bacteria with transferable multiple drug resistance. PLoS ONE, 11(1), 1-14. https://doi.org/10.1371/journal.pone.0146349

Waghmode, S., Pawar, S., Kalyankar, V., Dhamangaonkar, B., Dagade, S., \& Cukkemane, A. (2017). Biochemical profiling of antifungal activity of betel leaf(Piper betle L.) extract and its significance in traditional medicine. Journal of Advanced Research in Biotechnology, 2(1), 1-4. https://doi.org/10.15226/2475-4714/2/1/00116

Wang, C., Chen, H., Wu, Z., Jhan, Y., Shyu, C., \& Chou, C. (2016). Antibacterial and Synergistic Activity of Pentacyclic Triterpenoids Isolated from Alstonia scholaris. Molecules MDPI, 21, 111. https://doi.org/10.3390/molecules21020139 